\title{
Physico-Chemical Changes in Ready to Eat Pineapple Chicken Curry during Frozen Storage
}

\author{
Kappat Valiyapeediyekkal Sunooj ${ }^{1}$, Kolpe Radhakrishna ${ }^{2}$ \\ ${ }^{1}$ Department of Food Science \& Technology, Pondicherry University, Puducherry, India; ${ }^{2}$ Defence Food Research Laboratory, \\ Freeze-Drying and Animal Products Technology Division, Mysore, India. \\ Email: sunooj4u@gmail.com
}

Received July $4^{\text {th }}, 2012$; revised August $4^{\text {th }}, 2012$; accepted August $12^{\text {th }}, 2012$

\begin{abstract}
RTE Pineapple chicken curry, a traditional Kerala recipe, was prepared and standardized by using de-boned broiler meat chunks, pineapple and spices. The product having both meat and gravy (1:1.9) was packed in polyethylene pouches and stored at $-18^{\circ} \mathrm{C} \pm 2^{\circ} \mathrm{C}$ for 6 months. During frozen storage, the free fatty acid (FFA) values were 0.28 0.46 (as percentage oleic acid) and thiobarbituric acid (TBA) values were $1.68-2.45$ (mg of malonaldehyde $/ \mathrm{Kg}$ of sample) increased in both meat and gravy. Meat and gravy $\mathrm{pH}$ were in the range of 5.5 to 6 . Marginal decrease in shear force values $(43.4-39.6 \mathrm{~N})$ were also observed. During storage the SPC was found to be decreasing over period of storage $(100,40,20,<10$ respectively). Psychrophiles were within acceptable limit and pathogens were absent. Microbiological data showed that the product was microbiologically safe. The sensory score indicated that the RTE pineapple chicken curry is acceptable after storage at $-18^{\circ} \mathrm{C} \pm 2^{\circ} \mathrm{C}$ for 6 months.
\end{abstract}

Keywords: Chicken Curry; Pineapple; Frozen Storage; GC

\section{Introduction}

Globally several chicken recipes are very popular. Indian traditional meat based recipes are well known for its delicious and appetizing taste worldwide, but these foods require number of unit operations and long preparation time [1]. In order to minimize the tedious operations involved in preparation of food and to save time including all the required nutrition and to fulfill satiety of consumer especially for working population there is a need to develop several products that involve minimum processing. Ready to eat product has a budding industry in India and overseas, since needs of population is changing with time. Quality and safety of food is a major concern of both consumer and manufacturer that is influenced by several factors.

Indians have a variety of meat preparations that involves profuse use of spices that adds to the flavor as well as imparts antioxidant, antibacterial and various other functional roles. There are a number of products that vary in terms of preparation, kinds of meat, spices etc. Selection of suitable packaging material has been a great area of interest in order to maintain the shelf life and produce better products. Foods that have a short shelf life are processed for longer shelf life in variety of packaging materials such flexible films, multilayer packages, glass, cans etc. Canned products are available in market but has several limitations such as metal imparts an undesirable taste to the product during storage, is an expensive method and prone to a high incidence of leakage through seams [2]. Similarly retort pouches also need an additional processing before storage that adds to the cost but has an advantage that can be stored at room temperature for several months. Hence in the present study polythene pouches were used for packaging the product that were of low cost and also maintained the quality of food at frozen storage without any damage to the packaging material that usually is seen with other polymer materials such as polypropylene. Anon [3] suggested that curry products can be frozen and marketed in polythene pouches. Changes in quality during chilled or frozen storage have been studied in cod and haddock fillets [3], muscle of volador [4], buffalo meat burgers [5], chicken nuggets $[6,7]$ etc.

Kerala is known for its heavily spiced non vegetarian foods and pineapple chicken curry is one of the traditional recipes. A traditional recipe, pineapple chicken curry was prepared and packed in polyethylene bags and changes in its physico-chemical quality during frozen $\left(-18^{\circ} \mathrm{C} \pm 2^{\circ} \mathrm{C}\right)$ storage (for 6 months) were studied. An attempt was made in the present study to bring forth a standardized recipe for the pineapple chicken curry and also to cater the needs of working population and single 
person staying alone. These days a number of RTE are already available in market but still there is a need of proper marketing and awareness among the consumer for judicial utilization of upcoming technology and improved products so that both the consumer and the manufacturer can be benefited. Changes in the physicochemical quality of product were also determined in the course of technological processes of freezing and during storage of frozen products.

\section{Materials and Methods}

\subsection{Preparation of RTE Pineapple Chicken Curry}

Broiler chicken of $6-8$ weeks age were procured from the local market, dressed conventionally and were brought to the FD-APT division lab, Mysore, India. On the day of preparation, the carcasses $(1.10$ to $1.20 \mathrm{~kg})$ were washed under running tap water and deboned. Breast and leg muscles were cut into cubes of $2-3 \mathrm{~cm}$ and were marinated in curd for $1-2$ hours. This was cooked for $10-15 \mathrm{~min}$ at $95^{\circ} \mathrm{C}-100^{\circ} \mathrm{C}$ and cooled to $30^{\circ} \mathrm{C}-40^{\circ} \mathrm{C}$. The ingredient composition for the preparation of RTE pineapple chicken curry is given in Table $\mathbf{1}$. Cooking oil was heated in a stainless steel vessel to $110^{\circ} \mathrm{C}-120^{\circ} \mathrm{C}$, added clove, cinnamon and cardamom and roasted for 1 - 2 minutes. Sliced onion, ginger, garlic, coriander leaves and green chillies were added and sautéd till light golden colour. Then added tomato puree, red chilli powder, coriander powder, turmeric powder, salt and pineapple cubes and cooked for $4 \mathrm{~min}$ on low flame. To this gravy mix, added cooked chicken cubes along with cooked out juice and mixed well. This was further heated for $5 \mathrm{~min}$ at $85^{\circ} \mathrm{C}-90^{\circ} \mathrm{C}$. The product cooled to $30^{\circ} \mathrm{C}-40^{\circ} \mathrm{C}$ for $40-50 \mathrm{~min}$ and separated the meat chunks from gravy.

The product was packaged in polythene pouches ( 300 gauge) with $100 \mathrm{~g}$ meat and $250 \mathrm{~g}$ gravy in each pouch. The sealed packets placed in wax coated carton and frozen in a plate freezer until the product temperature reached $-45^{\circ} \mathrm{C}$ to $-60^{\circ} \mathrm{C}(115-125 \mathrm{~min})$. A digital temperature recorder with metallic probes (Aptec, Chennai, India) was used to ensure adequate temperature decline of the product. The frozen product was then stored at a freezer maintained at $-18^{\circ} \mathrm{C} \pm 2^{\circ} \mathrm{C}$.

\subsection{Quality Evaluation}

Physical, chemical and microbiological studies were conducted for 6 months of frozen storage. The product was thawed at $26^{\circ} \mathrm{C} \pm 2^{\circ} \mathrm{C}$ for $30 \mathrm{~min}$ and was subjected to the following analyses.

\subsubsection{Physical and Chemical Parameters}

Separated the meat chunks and gravy and homogenized
Table 1. Ingredients composition of pineapple chicken curry.

\begin{tabular}{cc}
\hline Ingredients & Amount \\
\hline Chicken Cubes & $2.22 \mathrm{Kg}$ \\
Pine apple & $300 \mathrm{~g}$ \\
Onion & $200 \mathrm{~g}$ \\
Green Chilli & $32.0 \mathrm{~g}$ \\
Salt & $22.0 \mathrm{~g}$ \\
Garlic & $23.0 \mathrm{~g}$ \\
Corn Flour & $10.0 \mathrm{~g}$ \\
Ginger & $23.0 \mathrm{~g}$ \\
Pepper & $2.00 \mathrm{~g}$ \\
Vegetable Oil & $75.0 \mathrm{ml}$ \\
Vinegar & $6 \mathrm{t} \mathrm{sp}$ \\
Soy sauce & $3 \mathrm{t} \mathrm{sp}$ \\
Tomato sauce & $100 \mathrm{~g}$ \\
Chili sauce & $20.0 \mathrm{~g}$ \\
Jaggery & $20.0 \mathrm{~g}$ \\
\hline
\end{tabular}

in a mixer for sampling. Proximate composition and $\mathrm{NaCl}$ content in chicken chunks and gravy were determined [8]. FFA, pH and TBA of both chicken chunks and gravy were determined periodically during the storage period. Free fatty acid (FFA) [7] and thiobarbituric acid (TBA) were determined by aqueous extraction procedure [9] and $\mathrm{pH}$ by immersing a glass calomel electrode directly into the sample using a pH meter (Cyberscan 1000, Eutech Instruments, Singapore). Shear values were measured in a Lloyds Texturometer (LR5K, Lloyd Instruments Ltd., Hampshire, UK) in $100 \mathrm{~kg}$ load cell at a speed of $50 \mathrm{~mm} / \mathrm{min}$ with a $1 \mathrm{~mm}$ thick blade using chicken chunks of $1 \times 1 \times 1.5 \mathrm{~cm}$ strips.

\subsubsection{Free Fatty Acid Content (FFA)}

The FFA content of the samples was estimated as per AOAC (1990) [8]. The FFA content of the samples was estimated as per AOAC (1990). A known quantity of fat extracted was taken in to a $100 \mathrm{ml}$ flask and $50 \mathrm{ml}$ of hot neutralised alcohol was added followed by $1-2 \mathrm{ml}$ of phenolphthalein reagent. The flask was shaken vigorously to dissolve all the fat content and titrated against $0.25 \mathrm{~N} \mathrm{NaOH}$ solutions to get a faint pink colour. From the titre value FFA content was calculated as follows:

$$
\begin{aligned}
& \text { Free Fatty Acid }(\% \text { as Oleic acid }) \\
& =\frac{\mathrm{ml} \text { of alkali } \times N \text { of alkali } \times 28.2}{\text { Weight of fat }(\mathrm{g})}
\end{aligned}
$$




\subsubsection{Thiobarbituric Acid Reactive Substance (TBARS) Determination}

TBARS values in meat/poultry samples were determined as per Taraldgis method [10]. Taraldgis method (1960) is one of the most widely used tests to evaluate the extent of lipid oxidation in meats. This is based on the reaction between important oxidation product malnaldehyde with TBA reagent to produce a colour complex. The chromogen results from the condensation of two molecules of TBA with one molecule of malonaldehyde.

$20 \mathrm{~g}$ of blended sample was accurately weighed and transferred into a RB flask. To that $2.5 \mathrm{ml}$ of conc. $\mathrm{HCl}$ was added along with $97.5 \mathrm{ml}$ of distilled water. $\mathrm{pH}$ was adjusted to 1.5. Mixture was steam distilled and $50 \mathrm{ml}$ distillate was collected in $10 \mathrm{~min}$. From this $25 \mathrm{ml}$ of distillate was transferred into stoppered glass tubes and 5 $\mathrm{ml}$ of TBA reagent was added. The test tubes were kept in boiling water bath for $35 \mathrm{~min}$ and it was cooled and OD was measured at $538 \mathrm{~nm}$. The TBARS values were calculated using the standard curve.

\subsubsection{Total Fatty Acid Analysis by Gas Chromatography}

\subsubsection{Esterification of Fatty Acids}

The samples were esterified as per the procedure of Metcalfe et al. [11] with slight modifications.

About $150 \mathrm{mg}$ of lipid was accurately weighed into a clean and dry stoppered test tube. $4 \mathrm{ml}$ of $0.5 \mathrm{~N}$ alcoholic sodium hydroxide solutions was added and heated for 5 min over a water bath at $90^{\circ} \mathrm{C}$. On cooling $5 \mathrm{ml}$ of Boron trifluoride-methanol reagent (14\%) was added and heated for $5 \mathrm{~min}$ at $90^{\circ} \mathrm{C}$ over a water bath, followed by addition of $10 \mathrm{ml}$ of saturated sodium chloride solution. The samples were thoroughly cooled to room temperature and 5 $\mathrm{ml}$ of hexane was added to each tube. It was shaken well and kept undisturbed. The upper hexane layer was drawn out into clean dry conical flask and dried over anhydrous sodium sulphate to remove the traces of moisture if present. The samples were filtered and transferred to stoppered clean dry tubes for gas chromatographic analysis.

\subsubsection{Quantification of Fatty Acid Analysis by Gas Chromatography}

Analysis of total fatty acids was carried out by ceres 800 , Chemito model Gas chromatograph fitted with BPX 70 column (25 mt, $0.32 \mathrm{~mm}$ ID) and flame ionisation detector. Temperature gradient programming was employed from $150^{\circ} \mathrm{C}$ to $220^{\circ} \mathrm{C}$. Split ratio was adjusted to $1: 25$ and capillary flow of carrier $2 \mathrm{ml} / \mathrm{min}$. Injector and detector port temperatures were adjusted as 230 and 240 respectively. For FID, Hydrogen and Oxygen was used and the flow was adjusted as $45 \mathrm{ml} / \mathrm{min}$ and $45 \mathrm{ml} / \mathrm{min}$ respectively. Along with samples standard esters of fatty acids were also injected and the fatty acids were detected by comparing the retention time of the standard esters of fatty acids. The quantification of the fatty acids was carried out by evaluating with the standard fatty acid esters area corresponding to each peak in the chromatogram. Iris 32 software is used to integrate and evaluate the chromatogram in the analysis.

\subsubsection{Microbiological Quality}

Chicken chunks in the curry were cut using a sterile knife and mixed with the gravy. Placed a $50 \mathrm{~g}$ sample of the mixture in a sterile stomacher bag containing $450 \mathrm{ml}$ sterile saline $(0.85 \% \mathrm{NaCl})$ solution and blended in a stomacher (Seward Stomacher 400, Seward Medical, London, UK). The blended samples were tested for standard plate counts (SPC), coliforms, yeast and mould (Y\&M), srtaphylococci, salmonella and E. coli by pour plate method [12].

\subsubsection{Sensory Quality}

Packets of RTE chicken curry was thawed by holding them at $26^{\circ} \mathrm{C} \pm 2^{\circ} \mathrm{C}$ and warmed the product in a hot pan maintained at $80^{\circ} \mathrm{C}-90^{\circ} \mathrm{C}$ for $3-4 \mathrm{~min}$. The coded samples were subjected to sensory evaluation by 10 in-house trained panelists using a 9-point hedonic scale $[6,13]$ and recorded the mean score of each attribute (colour, flavor, mouthfeel, consistency of the gravy, meat texture and overall acceptability).

\subsection{Statistical Analysis}

Statistical analysis was performed with SPSS software (SPSS Inc., 1996) and used to test the significant effect of various parameters at 5\% level of significance $(\mathrm{P}>$ $0.05)$. Each test was performed in replication of three.

\section{Results and Discussion}

\subsection{Physical and Chemical Quality}

In the present RTE recipe pineapple used were different from other regular chicken curry recipe. Pineapple had certain advantages and made the recipe much more acceptable. Pineapple has exceptional juiciness that added to the curry and vibrant flavor with several health benefits. The enzyme bromelain present enhanced the texture of chicken by tenderizing and maintained it for longer also the highly acidic nature of fruit lowered the $\mathrm{pH}$ thus extending the shelf life. Chicken chunks were found to have less moisture, fat, ash and salt compared to gravy i.e. $69.40 \%, 11.08 \%, 1.80 \%$ and $1.58 \%$ respectively in chunks whereas in gravy a higher values were observed i.e. $74.5 \%, 13.43 \%, 1.9 \%$ and $1.8 \%$ respectively. The higher values in gravy can be contributed due to the added spices, salt and water during cooking of the chicken curry but since chicken is a good source of protein whereas in gravy no ingredient that has as high pro- 
tein content in chunks $(19.43 \%)$ thus curry had a significant lower value for protein i.e. $2.7 \%$. The physio-chemial changes during frozen storage of pineapple chicken curry were depicted in Table 2 . There was marginal fall in the $\mathrm{pH}$ (Table 2) of meat and gravy from 5.7 to 5.51 and 6.02 to 5.68 respectively during 6 months of frozen storage. FFA values (as \% of oleic acid) were increased marginally from 0.28 to 0.453 in meat and 0.29 to 0.46 in gravy during frozen storage for 6 months (Table 2).

Lipase activity has been reported as the cause of increased FFA values in meat products during storage by many authors. But the increase in FFA did not increase the rancidity in pork sausages [14,15], fried chicken [16], buffalo meat burgers [6] and chicken nuggets [7]. Increased level of FFA does not cause any toxicological effects [17].

TBA is a measure of oxidative rancidity of the product. TBA values (mg of malonaldehyde/ $\mathrm{kg}$ sample) fluctuated non-significantly between 1.68 and 2.64 for meat and 2.21 and 2.45 for gravy during the storage period (Table 2). This effect is attributed to the very low temperature storage and the antioxidant effect of the spices used [18-20].

A significant $(\mathrm{P} \leq 0.05)$ increase in TBA value during frozen storage was reported in chicken nuggets [6,21], Iberian ham [22] (Martin et al., 2000), and fish fingers [23] and buffalo meat burgers [2003]. Wang et al. [24] has reported TBA values of around 2.0 in fresh chicken meat after vacuum packaging and storage for 7 weeks at $7^{\circ} \mathrm{C}$.

\subsection{Texture}

The shear values for meat pieces observed a marginal decrease (17.64\%) during 6 month frozen storage (Table 2), indicating that the freezing and storage in frozen condition has little effect on the textural qualities of meat in the curry. Initially, the samples required higher shear force i.e. $34 \mathrm{~N}$ but during storage the force decreased to $28 \mathrm{~N}$. This decrease in shear force can be attributed to both cooking and freezing process. Combes et al. [25] suggested that with advancement in cooking process several changes occur due to heat application as well as mechanical properties are influenced. Similarly, freezing also leads to textural changes as during the process of freezing ice crystals are formed in between the fibres that causes stretching and ruptures of connective tissues thus inducing higher tenderization. Hence there is a decrease in shear force values during freezing. Also, Shanks et al. [26] have reported that tenderization in meat is highly dependent on freezing rate, storage temperature and frozen storage duration that affect the amount of intracellular crystal formation and physical disruption occurring in muscle.

\subsection{Microbiological Quality}

Various microbiological tests were carried out have shown that freshly prepared chicken curry (before freezing) had microbial counts of $1 \times 10^{2}$ and $2 \times 10^{1}$ (in $\log \mathrm{cfu} / \mathrm{g}$ ) for SPC, yeasts and molds respectively (Table 3). Banwart [27] suggested that microbial specifications for cooked poultry products should be in the range of 4 $5 \mathrm{log} \mathrm{cfu} / \mathrm{g}$ for aerobic plate counts. During freezing microbes become dormant thus, there is limited or no microbial spoilage at low temperature [28]. Studies have revealed that beef frozen for up to 90 days did not spoiled due to microbial growth [29]. S. aureus, coliform, salmonella and $E$. coli could not be detected in these products.

After a period of 6 months a decrease in both SPC and yeasts \& molds count were observed to $<10$ and 10 respectively that can be due to decrease in $\mathrm{pH}$ that was observed with an increase in storage period. Absence of $S$. aureus, coliform, salmonella and E. coli can be contributed by thermal processing initially followed by hy-

Table 2. Changes in physicochemical quality of chunks and gravy.

\begin{tabular}{|c|c|c|c|c|c|c|c|c|}
\hline \multirow{2}{*}{$\begin{array}{l}\text { Storage period } \\
\text { (in months) }\end{array}$} & \multicolumn{2}{|c|}{$\mathbf{p H}$} & \multicolumn{2}{|c|}{ FFA (as percentage oleic acid) } & \multicolumn{2}{|c|}{$\begin{array}{c}\text { TBA (mg malonaldehyde per } \\
\text { Kg fat) }\end{array}$} & \multicolumn{2}{|c|}{ Shear force $(\mathbf{N})$} \\
\hline & In Meat Sample & In Gravy & In Meat Sample & In Gravy & In Meat Sample & In Gravy & In Meat Sample & In Gravy \\
\hline $\mathbf{0}$ & $5.73 \pm 0.03$ & $6.02 \pm 0.11$ & $0.28 \pm 0.02$ & $0.29 \pm 0.05$ & $1.68 \pm 0.11$ & $2.21 \pm 0.06$ & - & - \\
\hline 1 & $5.65 \pm 0.05$ & $5.90 \pm 0.05$ & $0.31 \pm 0.02$ & $0.35 \pm 0.04$ & $2.00 \pm 0.23$ & $2.32 \pm 0.04$ & $34 \pm 1.52$ & - \\
\hline 3 & $5.68 \pm 0.09$ & $5.70 \pm 0.10$ & $0.28 \pm 0.04$ & $0.37 \pm 0.04$ & $2.03 \pm 0.25$ & $2.25 \pm 0.02$ & $32 \pm 1.20$ & - \\
\hline 4 & $5.60 \pm 0.17$ & $5.70 \pm 0.10$ & $0.34 \pm 0.01$ & $0.35 \pm 0.04$ & $2.08 \pm 0.09$ & $2.25 \pm 0.22$ & $31 \pm 1.52$ & - \\
\hline 5 & $5.55 \pm 0.03$ & $5.69 \pm 0.02$ & $0.41 \pm 0.05$ & $0.44 \pm 0.06$ & $2.19 \pm 0.20$ & $2.30 \pm 0.20$ & $29 \pm 1.23$ & - \\
\hline 6 & $5.51 \pm 0.01$ & $5.68 \pm 0.09$ & $0.45 \pm 0.07$ & $0.46 \pm 0.04$ & $2.34 \pm 0.13$ & $2.45 \pm 0.08$ & $28 \pm 1.92$ & - \\
\hline
\end{tabular}

$\operatorname{Mean} \pm \mathrm{SD}, \mathrm{n}=3$ 
Table 3. Changes in microbiological quality (counts in log cfu/g) of pineapple chicken curry during frozen storage $\left(-18^{\circ} \mathrm{C} \pm 2^{\circ} \mathrm{C}\right)$.

\begin{tabular}{ccccccc}
\hline Samples & SPC & Coliform & $\begin{array}{c}\text { Yeast \& } \\
\text { Mold }\end{array}$ & \multicolumn{2}{c}{ S. aureus Salmonella } & E.coli \\
\hline Fresh & $1 \times 10^{2}$ & Nil & $2 \times 10^{1}$ & Nil & Nil & Nil \\
2 Months & $4 \times 10^{1}$ & Nil & $1 \times 10^{1}$ & Nil & Nil & Nil \\
4 Months & $2 \times 10^{1}$ & Nil & $1 \times 10^{1}$ & Nil & Nil & Nil \\
6 Months & $<10$ & Nil & $1 \times 10^{1}$ & Nil & Nil & Nil \\
\hline
\end{tabular}

gienic packaging in addition to the antibacterial effect of spices [30,31]. Finally before storage, samples were subjected to low temperature that also had an inhibitory effect on the growth of undesirable microbes and preventing spoilage. Narasimha et al. [32] suggested that meat products are spoiled when an off odor, slime formation along with the microbial population of $8 \log \mathrm{cfu} / \mathrm{g}$ on the surface is evident.

\subsection{Fatty Acid Estimation by Gas Chromatography}

The individual fatty acid composition of pineapple chicken curry were estimated to find out the effect of pineapple on fat oxidation during storage. The stability of various saturated, monounsaturated and polyunsaturated fatty acids during 6 months storage at $-18^{\circ} \mathrm{C}$ were evaluated. The results of this study were depicted in Table 4. From the table it could be observed that the sample contains a mixture of fatty acids both saturated and unsaturated fatty acids. Unsaturated fatty acids constitute both monounsaturated (MUFA) and polyunsaturated (PUFA). Monounsaturated fatty acids are dominant and constitute approximately $52 \%$. The oxidation of lipid is one of the primary causes of deterioration of meat during processing and storage leading to development of off-flavour, decrease in nutritive value, loss of colour, texture etc. So the degradation of un- saturated fatty acids have been investigated by GC.

From the data, it could be clear that, out of saturated fatty acids lauric, myristicand palmitic found in low quantities. Stearic contribute the major mono unsaturated fatty acids. The PUFA i.e., linoleic, linolenic and arahidonic acids were also present in small quantities. From the studies, it was observed that saturated fatty acids do not vary significantly during storage, where as MUFA and PUFA showed a significant change during storage.

\subsection{Sensory Quality}

Mean sensory scores given by panel members for 0-day samples for overall acceptability were in the range of $8.34 \pm 0.32$ on a 9-point hedonic scale (Table 5). During the storage period of 6 months a gradual decrease in scores were observed from 8.34 to 7.46 on 0 day and after 6 months of frozen storage respectively. The scores given by panel members have shown that the samples

Table 4. Fatty acid profile of sample.

\begin{tabular}{ccc}
\hline Fatty acid & Gram percentage & Gram percentage \\
\hline Initial & 6 Months \\
\hline Lauric (C12:0) & $0.76 \pm 0.03$ & $0.75 \pm 0.06$ \\
Mysitic (C14:0) & $5.40 \pm 0.21$ & $5.32 \pm 0.19$ \\
Palmitic (C16:0) & $17.61 \pm 0.12$ & $17.49 \pm 0.15$ \\
Palmitoleic (C16:1) & $3.02 \pm 0.09$ & $2.85 \pm 0.07$ \\
Stearic (C18:0) & $20.23 \pm 0.24$ & $19.91 \pm 0.21$ \\
Oleic (C18:1) & $32.34 \pm 0.14$ & $31.51 \pm 0.17$ \\
Linoleic (C18:2) & $11.4 \pm 0.17$ & $11.06 \pm 0.20$ \\
Linolenic (C18:3) & $1.5 \pm 0.02$ & $1.24 \pm 0.04$ \\
Arachidonic(C20:4) & $0.82 \pm 0.12$ & $0.64 \pm 0.13$ \\
\hline
\end{tabular}

Mean \pm SD, $\mathrm{n}=3$.

Table 5. Changes in sensory quality of pineapple chicken curry product during frozen $\left(-18^{\circ} \mathrm{C} \pm 2^{\circ} \mathrm{C}\right)$ storage.

\begin{tabular}{cccccccc}
\hline & \multicolumn{7}{c}{ Storage period in months } \\
\cline { 2 - 8 } & $\mathbf{0}$ & $\mathbf{1}$ & $\mathbf{2}$ & $\mathbf{3}$ & $\mathbf{4}$ & $\mathbf{5}$ & $\mathbf{6}$ \\
\hline Colour & $8.6 \pm 0.23$ & $8.5 \pm 0.23$ & $8.3 \pm 0.32$ & $8.2 \pm 0.21$ & $8.0 \pm 0.26$ & $7.9 \pm 0.35$ & $7.8 \pm 0.43$ \\
Flavour & $8.3 \pm 0.27$ & $8.3 \pm 0.27$ & $8.1 \pm 0.32$ & $8.0 \pm 0.29$ & $7.8 \pm 0.46$ & $7.6 \pm 0.36$ & $7.4 \pm 0.32$ \\
Mouth feel & $8.4 \pm 0.23$ & $8.1 \pm 0.32$ & $8.0 \pm 0.45$ & $7.9 \pm 0.42$ & $7.7 \pm 0.42$ & $7.6 \pm 0.24$ & $7.5 \pm 0.28$ \\
Consistency & $8.2 \pm 0.32$ & $8.3 \pm 0.42$ & $8.0 \pm 0.78$ & $7.9 \pm 0.64$ & $7.7 \pm 0.74$ & $7.6 \pm 0.74$ & $7.5 \pm 0.64$ \\
Texture & $8.2 \pm 0.54$ & $8.4 \pm 0.42$ & $8.0 \pm 0.68$ & $7.7 \pm 0.24$ & $7.4 \pm 0.32$ & $7.3 \pm 0.86$ & $7.1 \pm 0.32$ \\
OAA & $8.34 \pm 0.32$ & $8.32 \pm 0.33$ & $8.08 \pm 0.51$ & $7.94 \pm 0.36$ & $7.72 \pm 0.44$ & $7.6 \pm 0.51$ & $7.46 \pm 0.4$ \\
\hline
\end{tabular}

Mean \pm SD. 
maintained the quality even after the storage period of 6 months under frozen conditions since all the scores were observed above 7 that are in an acceptable range. Similarly a decrease in trend was observed for beef patties [33], chicken nuggets [7] and egg loaf [34] and chicken curry [1].

\section{Conclusion}

Consumer's rising interest in RTE has motivated researchers to standardize the process of traditional products that are long being known as well as are highly consumed. In the present study recipe of pineapple chicken curry was standardized that was packed and analysed for six months which revealed that even after a storage period of 6 months the product was accepted by the sensory panelists as well as was found to be microbiologically stable. A decreased $\mathrm{pH}$ further contributed to decrease in stability. FFA and TBA values have shown that there was no adverse affect on the nutritional quality due to the combined effect of low temperature and antioxidant effect of spices used. Fatty acid profile has been established by GC and several fatty acids were quantified. Thus, the product quality was maintained and it can be concluded that it can be stored without marked loss in quality for a period of 6 months at $-18^{\circ} \mathrm{C} \pm 2^{\circ} \mathrm{C}$.

\section{REFERENCES}

[1] V. K. Modi, N. M. Sachindra, A. D. Sathisha, N. S. Mahendrakar and D. Narasimha Rao, "Changes in Quality of Chicken Curry during Frozen Storage," Journal of Muscle Foods, Vol. 17, No. 2, 2006, pp. 141-154. doi:10.1111/j.1745-4573.2006.00034.x

[2] T. K. Srinivasa Gopal, T. S. G. Iyer, K. K. Balachandran, P. Madhavan, P. K. Vijayan and C. N. Ravishankar, "Ready to Eat Fish Curry in Flexible Packs," Seafood Export Journal, Vol. 30, No. 1, 1999, pp. 7-11.

[3] Anonymous, "New Fast Food Ideas Take Shape at Chic-ORoll," Frozen Chilled Food, Vol. 37, No. 8, 1984, pp. 24-25.

[4] F. Badii and N. K. Howell, "Changes in the Texture and Structure of Cod and Haddock Fillets during Frozen Storage," Food Hydrocolloids, Vol. 16, No. 4, 2002, pp. 313-319. doi:10.1016/S0268-005X(01)00104-7

[5] C. R. Capillas, A. Moral, J. Morales and P. Montero, "The Effect of Frozen Storage on the Functional Properties of the Muscle of Volador (Illex Coindetii)," Food Chemistry, Vol. 78, No. 2, 2002, pp. 149-156. doi:10.1016/S0308-8146(01)00392-2

[6] V. K. Modi, N. S. Mahendrakar, D. Narasimha and N. M. Sachindra, "Quality of Buffalo Meat Burger Containing Legume Flours as Binders," Meat Science, Vol. 66, No. 1, 2003, pp. 143-149.

[7] V. K. Modi, N. S. Mahendrakar, N. M. Sachindra and D. Narasimha, "Quality of Nuggets Prepared from Fresh and
Smoked Spent Layer Chicken Meat," Journal of Muscle Foods, Vol. 15, No. 3, 2004, pp. 195-204. doi:10.1111/j.1745-4573.2004.tb00684.x

[8] AOAC (Association of Official Analytical Chemist), "Official Methods of Analysis, Association of Official Analytical Chemists," 15th Edition, AOAC Press, Gaithersburg, 1990.

[9] J. Pikul, D. E. Leszczynski and F. A. Kummerow, "Evaluation of Three Modified TBA Methods for Measuring Lipid Oxidation in Chicken Meat," Journal of Agriculture Food Chemistry, Vol. 37, No. 5, 1989, pp. 1309-1313. doi:10.1021/if00089a022

[10] B. G. Tarladgis, B. M. Watts and M. T. Youthan, "A Distillation Method for the Quantitative Determination of Malonaldehyde in Rancid Foods," Journal of the American Oil Chemists Society, Vol. 37, No. 1, 1960, pp. 44-48. doi:10.1007/BF02630824

[11] L. D. Metcalfe, A. A. Schmitz and J. R. Pelka, "Rapid Preparation of Fatty Acid Esters from Lipids for Gas Chromatographic Analysis," Analytical Chemistry, Vol. 38, No. 3, 1966, pp. 514-515. doi:10.1021/ac60235a044

[12] APHA, "Compendium of Methods for the Microbiological Examination of Foods," 4th Edition, American Pubic Health Association, Washington DC, 2001.

[13] ASTM (American Society for Testing Materials), "Manual Series MNL 26," 2nd Edition, American Society for Testing and Materials, Philadelphia, 1996.

[14] M. C. D. Fernandez and I. M. Z. Rodriguez, "Lipolytic and Oxidative Changes in 'Chorizo' during Ripening," Meat Science, Vol. 29, No. 2, 1991, pp. 99-107. doi:10.1016/0309-1740(91)90057-W

[15] I. Zalacain, M. J. Zapelena, I. Astiasaran and J. Ballo, "Dry Fermented Sausages Elaborated with Lipase from Candida cylindacea: Comparison with Traditional Formulations," Meat Science, Vol. 40, No. 1, 1995, pp. 55-61. doi:10.1016/0309-1740(94)00023-Z

[16] K. P. Yashoda, V. K. Modi, N. S. Mahendrakar, N. M. Sachidra and D. Narasimha Rao, "Quality Characteristics of Fried Broiler Chicken Prepared by Two Processing Methods," Food Research International, Vol. 14, No. 3, 2004, pp. 163-173. doi:10.1111/j.1745-4506.2004.tb00187.x

[17] M. E. Camire, A. Camire and K. Kumber, "Chemical and Nutritional Changes in Food during Extraction," Critical Review Food Science and Nutrition, Vol. 29, No. 1, 1990, pp. 35-57. doi:10.1080/10408399009527513

[18] S. S. L. Abd-El-Alim, A. Lugasi, J. Hovari and E. Dworschak, "Culinary Herbs Inhibit Lipid Oxidation in Raw and Cooked Minced Meat Patties during Storage," Journal of the Science of Food and Agriculture, Vol. 79, No. 2, 1999, pp. 277-285.

doi:10.1002/(SICI)1097-0010(199902)79:2<277::AID-JS FA181>3.0.CO;2-S

[19] D. E. Pszczola, "Antioxidants: From Preserving Food Quality to Quality of Life," Food Technology, Vol. 55, No. 6, pp. 51, 52, 54-57.

[20] P. F. Leal, M. E. M. Braga, D. N. Sato, J. E. Carvalho, M. O. M. Marques and M. A. A. Meireles, "Functional Prop- 
erties of Spice Extracts Obtained via Supercritical Fluid Extraction," Journal of Agricultural and Food Chemistry, Vol. 51, No. 9, 2003, pp. 2520-2525. doi:10.1021/if0260693

[21] S. M. Lai, J. I. Gray, A. M. Booren, R. L. Crackel and J. L. Gill, "Assessment of off Flavour Development in Restructured Chicken Nuggets Using Hexanal and TBARS Measurements and Sensory Evaluation," Journal of Agricultural and Food Chemistry, Vol. 67, No. 4, 1995, pp. 447-452. doi:10.1002/jsfa.2740670405

[22] L. Martin, M. L. Timan, M. J. Patron, J. Ventans and T. Antequena, "Evolution of Volatile Aldehydes in Iberian Ham Matured under Different Processing Conditions," Meat Science, Vol. 54, No. 4, 2000, pp. 333-337. doi:10.1016/S0309-1740(99)00107-2

[23] L. Reddy, T. M. R. Setty and K. C. Dora, "Studies on Storage Behavior of Frozen Fish Fingers from Croacker and Perches," Fish Technology, Vol. 29, No. 1, 1992, pp. 35-39.

[24] S. H. Wang, M. H. Chang and T. C. Chen, "Shelf-Life and Microbiological Profiler of Chicken Wing Products Following Sous vide Treatment," International Journal of Poultry Science, Vol. 3, No. 5, 2004, pp. 326-332. doi:10.3923/ijps.2004.326.332

[25] S. Combes, J. Lepetit, B. Darche and F. Lebas, "Effect of Cooking Temperature and Cooking Time on WarnerBratzler Tenderness Measurements and Collagen Content in Rabbit Meat," Meat Science, Vol. 66, No. 1, 2003, pp. 91-96. doi:10.1016/S0309-1740(03)00019-6

[26] B. C. Shanks, D. M. Wulf and R. J. Maddock, "Technical Note: The Effect of Freezing on Warner-Bratzler Shear Force Values of Beef Longissimus Steaks across Several Post-Mortem Aging Periods," Journal of Animal Science, Vol. 80, No. 8, 2002, pp. 2122-2125.
[27] G. J. Banwart, "Regulations and Standards," In: Basic Food Microbiology, AVI Publishing Co., Inc., Westport, 1989, p. 738.

[28] C. Leygonie, T. J. Britz and L. C. Hoffman, "Impact of Freezing and Thawing on the Quality of Meat: Review," Meat Science, Vol. 91, No. 2, 2012, pp. 93-98. doi:10.1016/j.meatsci.2012.01.013

[29] C. Vieira, A. Cerdeño, E. Seffano, P. Lavín and A. R. Mantecón, "Breed and Ageing Extent on Carcass and Meat Quality of Beef from Adult Steers (Oxen)," Livestock Science, Vol. 107, No. 1, 2007, pp. 62-69. doi:10.1016/j.livsci.2006.09.004

[30] B. M. Grohs and B. Kunz, "Antimicrobial Effect of Spices on Sausage Type Frankfurter," Advance Food Science, Vol. 21, No. 3-4, 1999, pp. 128-135.

[31] B. M. Grohs, N. Kleigel and B. Kunz, "Bacteria Grow Slower: Effects of Spice Mixtures on Extension of Shelf Life of Pork," Fleischwirtschaft, Vol. 80, No. 9, 2000, pp. 61-63.

[32] D. Narasimha Rao, K. K. S. Nair and P. Z. Sakhare, "Meat Microbiology and Spoilage in Tropical Countries," In: A. Davies and R. Board, Eds., The Microbiology of Meat and Poultry, Blackie Academic \& Professional, London, 1998, pp. 220-265.

[33] K. B. Bullock, D. L. Huffman, W. B. Egbert, W. B. Mikel, D. D. Bradford and W. R. Jones, "Storage Stability of Low Fat Ground Beef Made with Lower Value Cuts of Beef," Journal of Food Science, Vol. 59, No. 1, 1994, pp. 6-9. doi:10.1111/j.1365-2621.1994.tb06884.x

[34] K. P. Yashoda, R. Jagannatha Rao, N. S. Mahendrakar and D. Narasimha Rao, "Egg Loaf and Changes in Its Quality during Storage," Food Control, Vol. 15, No. 7, 2004, pp. 523-526. doi:10.1016/j.foodcont.2003.08.004 